Pesq. Vet. Bras. 37(5):491-494, maio 2017 DOI: $10.1590 / \mathrm{S} 0100-736 \mathrm{X} 2017000500011$

\title{
Feline immunodeficiency virus (FIV), feline leukaemia virus (FeLV) and Leishmania sp. in domestic cats in the Midwest of Brazil ${ }^{1}$
}

\author{
Daniella Poffo ${ }^{2}$, Arleana B.P.F. Almeida², Luciano Nakazato² ${ }^{2}$ Valéria Dutra ${ }^{2}$, Sandra \\ H.R. Correa ${ }^{2}$, Adriane J. Mendonça² and Valéria R.F. Sousa ${ }^{2 *}$
}

\begin{abstract}
Poffo D., Almeida A.B.P.F., Nakazato L., Dutra V., Correa S.H.R., Mendonça A.J. \& Sousa V.R.F. 2017. Feline immunodeficiency virus (FIV), feline leukaemia virus (FeLV) and Leishmania sp. in domestic cats in the Midwest of Brazil. Pesquisa Veterinária Brasileira 37(5):491-494. Departamento de Clínica Médica Veterinária, Faculdade de Medicina Veterinária, Universidade Federal de Mato Grosso, Av. Fernando Corrêa da Costa 2367, Boa Esperança, Cuiabá, MT 78900-060, Brazil. E-mail: regia@ufmt.br

This search aimed to investigate FIV and FeLV infections in domestic cats, analysing the epidemiological profile of the disease as well as additional infection with Leishmania sp. We evaluated 88 domestic cats for the presence of FIV, FeLV and Leishmania sp. infection. Eleven (12.5\%) cats were positive for FIV infection, four (4.5\%) were positive for FeLV, and two were co-infected. However, none was infected with Leishmania sp. The prevalence for FIV infection was higher than FeLV, and those observed in other regions, but no factor was associated with the infection by FIV and FeLV in this study.
\end{abstract}

INDEX TERMS: Feline, FIV, FeLV, visceral leishmaniasis, PCR.

RESUMO.- [Infecção por Vírus da Imunodeficiência Felina (FIV), vírus da leucemia felina (FeLV) e Leishmania sp. em gatos domésticos no Centro-Oeste do Brasil.] Esta pesquisa teve o objetivo de investigar a infecção em gatos domésticos por FIV e FeLV, analisando o perfil epidemiológico destas doenças, assim como a infecção por Leishmania sp. Oitenta e oito gatos domésticos foram avaliados pesquisando a infecção por FIV, FeLV e Leishmania sp. Onze $(12,5 \%)$ gatos foram positivos para infecção por FIV, quatro $(4,5 \%)$ para FeLV, e dois gatos apresentaram co-infecção pelos dois vírus. Entretanto, nenhum gato doméstico apresentou infecção por Leishmania sp. A prevalência da infecção para FIV foi maior que a observada para FeLV, e que a observada em outras regiões, mas nenhum fator teve associação à infecção neste estudo.

TERMOS DE INDEXAÇÃO: Felino, FIV, FeLV, leishmaniose visceral, PCR.

\footnotetext{
${ }^{1}$ Received on October 15, 2015.

Accepted for publication on July 15, 2016.

${ }^{2}$ Departamento de Clínica Médica Veterinária, Faculdade de Medicina Veterinária, Universidade Federal de Mato Grosso (UFMT), Avenida Fernando Corrêa da Costa 2367, Boa Esperança, Cuiabá, MT Brasil. *Corresponding author: regia@ufmt.br
}

\section{INTRODUCTION}

Feline immunodeficiency virus (FIV) and feline leukaemia virus (FeLV) are retroviruses found within domestic cats around the world (Chhetri et al. 2015). Both viruses can be transmitted horizontally via saliva or other body fluids, and vertical transmission can also occur (Munro et al. 2014). The resultant infections are accompanied by dysfunction of the immune system, making the cats susceptible to other diseases (Hartmann 2012). Clinical manifestations due to the specific actions of the viruses, such as feline gingivitis-stomatitis complex in the case of FIV and lymphoma in certain FeLV-infected cats, have also been described (Beatty 2014).

In Brazil, related studies are still scarce, although a survey of data from several regions yielded prevalence ranging from 4.14 to $21.5 \%$ for FIV and from 10.8 to $32.5 \%$ for FeLV (Teixeira et al. 2007). There are no reports on the prevalence of these viruses in domestic cats in the Midwest of the country, where research has been performed only on wild felids kept in captivity (Schmitt et al. 2003).

Several serological tests detect the presence of antibodies against FIV proteins (p24 core protein or gp 40 transmembrane protein) and the presence of soluble antigen of FeLV (p27 core protein). Among the serological tests, for FIV testing, Snap Combo Plus is recommended as the best 
performing in-clinic test, while for FeLV, the positive predictive value was $73.5 \%$ (Hartmann et al. 2007). However, molecular methods are more sensitive and specific to detect the pathogen during the first 2-4 weeks post-infection, as well as during the terminal stages of infection by FIV therefore the antibody response is generally low (Wilkes et al. 2015).

Infections with FIV and FeLV appear to increase the frequency of opportunistic infections, such as infection with Leishmania sp., for which felines are considered alternative hosts in endemic areas, such as Cuiaba, the capital of Mato Grosso (Dahroug et al. 2010, Sobrinho et al. 2012). In endemic areas for canine leishmaniosis, the subclinical feline infection by Leishmania are common, while clinical illness is rare. There is limited information on epidemiological and clinical manifestations of these infection (Pennisi et al. 2015).

Thus, the aim of the present study was to investigate FIV and FeLV infections in domestic cats and wild felids, analysing the epidemiological profile of the disease as well as additional infection with Leishmania sp.

\section{MATERIALS AND METHODS}

A transversal study was performed on 88 domestic cats healthy $(17 / 19.3 \%)$ or sick $(71 / 80.7 \%)$ at the University Veterinary Hospital in the city of Cuiabá, Mato Grosso State $\left(15^{\circ} 35^{\prime} 46^{\prime \prime} \mathrm{S} 56^{\circ}\right.$ 05' 48" W), in the Midwest of Brazil. The minimum sample size was defined as 71 cats, finite population of 310 cats, with an expected prevalence of $6.4 \%$ (Alves et al. 2011), an acceptable error rate of $5 \%$ and a $95 \%$ confidence interval, as defined by Epi Info 6.0 (Centers for Disease Control and Prevention [CDC], Atlanta, GA, USA). A questionnaire on the lifestyle and habits of the felines was given to each owner, followed by clinical evaluation of the felines and collection of blood samples by puncturing the jugular vein.

The blood samples were processed with EDTA for CBC automatic analysis and with phenol/chloroform/alcohol isoamyl (Sambrook et al. 1989) for DNA extraction, with later detection of FIV by nested PCR and of Leishmania by PCR.
The serum was used for the detection of FIV and FeLV using the IDEXX SNAP FIV/FeLV Combo Test diagnostic kit (IDEXX Laboratories, Markham, Ontario) in accordance with the manufacturer's recommendations.

PCR for detection of FIV (Lara et al. 2008) and Leishmania sp. (Degrave et al. 1994) was performed using the primers listed in Table 1 in all samples. In all PCR reactions, used DNA reference strain of L. infantum (MHOM/BR/1974/PP75) and for FIV, we used one sequenced sample (unpublished data). For negative control we used the DNA-free reaction. For FIV and Leishmania sp., the amplification products were fractionated by 1.5 or $2.0 \%$ agarose gel electrophoresis, respectively, stained with ethidium bromide and analysed using a transilluminator (UV 300nm).

Table 1. Primers used to detect FIV and Leishmania sp. and their expected amplicon sizes

\begin{tabular}{|c|c|c|}
\hline $\begin{array}{l}\text { Primers } \\
\text { name }\end{array}$ & Sequence $5^{\prime}-3^{\prime}$ & Amplicons \\
\hline FIV PCR S2 & AATATGACTGTATCTACTGC & $658 b p$ \\
\hline FIV PCR A2 & TTTTCTTCTAGAGTACTTTCTGG & \\
\hline $\begin{array}{l}\text { FIV } \\
\text { NESTED S }\end{array}$ & TATTCAAACAGTAAATGGAG & 329bp \\
\hline $\begin{array}{l}\text { FIV } \\
\text { NESTED A }\end{array}$ & CTGCTTGTTGTTCTTGAGTT & \\
\hline $\begin{array}{l}150 \\
152\end{array}$ & $\begin{array}{l}\text { GGG(G/T)AGGGGCGTTCT(C/G)CGAA } \\
(\mathrm{C} / \mathrm{G})(\mathrm{C} / \mathrm{G})(\mathrm{C} / \mathrm{G})(\mathrm{A} / \mathrm{T}) \mathrm{CTAT}(\mathrm{A} / \mathrm{T}) \mathrm{TTACACCAACCCC}\end{array}$ & $120 \mathrm{bp}$ \\
\hline
\end{tabular}

The data were analysed using the nonparametric chi-square test or Fisher's exact test via Epi Info 6.0 (CDC, Atlanta, GA, USA). Agreement between the diagnostic techniques for FIV was determined using sensibility, specificity and Cohen's kappa coefficient $(\kappa)$, consider ELISA tests as the gold standard. A $\kappa$ value of 0.2-0.6 represents fair to moderate agreement, a $\kappa$ value of $0.6-0.8$ represents substantial agreement, and a $\kappa$ value of $>0.8$ represents nearly complete agreement.

\section{RESULTS}

Eleven (12.5\%; CI: 5.7-19.3) of the cats were positive for FIV infection, four (4.5\%; CI: 1.1-9.1) were positive for FeLV, and two cats were co-infected (Table 2).

Table 2. Clinical and haematological characteristics of cats with infection by FIV and / or FeLV

\begin{tabular}{|c|c|c|c|c|c|c|c|c|c|}
\hline Cat & $\begin{array}{c}\text { Age } \\
\text { (year) }\end{array}$ & Gender & $\begin{array}{l}\text { Street } \\
\text { access }\end{array}$ & Origin & Clinical features & Haematological findings & ELISA FIV & PCR FIV & ELISA FeLV \\
\hline 1 & 3 & M & Yes & Cattery & Lymphadenomegaly & & + & + & - \\
\hline 2 & 7 & M & No & Stray & $\begin{array}{l}\text { Lymphadenomegaly, weight loss, } \\
\text { dehydration, otitis, FCG* }\end{array}$ & $\begin{array}{l}\text { Anemia, thrombocytopenia, } \\
\text { hyperproteinemia }\end{array}$ & + & + & - \\
\hline 3 & 8 & M & Yes & Stray & $\begin{array}{l}\text { Lymphadenomegaly weight loss, } \\
\text { anorexia, dehydration, FCG* }\end{array}$ & $\begin{array}{l}\text { Anemia, } \\
\text { hyperproteinemia }\end{array}$ & + & + & + \\
\hline 4 & 3 & $\mathrm{~F}$ & Yes & Stray & $\begin{array}{l}\text { Anorexia, emesis, } \\
\text { galactorrhoea }\end{array}$ & Thrombocytopenia & + & - & - \\
\hline 5 & 12 & M & Yes & stray & Dermatitis & Lymphopenia & + & - & + \\
\hline 6 & 5 & $\mathrm{~F}$ & No & stray & Lymphadenomegaly & & + & - & - \\
\hline 7 & 11 & $\mathrm{~F}$ & No & Stray & Lymphadenomegaly, FCG* & & + & - & - \\
\hline 8 & 2 & M & No & Stray & FLUTD** & Lymphopenia & + & + & - \\
\hline 9 & 8 & M & No & Stray & weight loss, FCG* & $\begin{array}{l}\text { Leukopenia, lymphopenia, } \\
\text { thrombocytopenia }\end{array}$ & + & + & - \\
\hline 10 & 9 & M & Yes & Stray & & Hyperproteinemia & + & - & - \\
\hline 11 & 2 & M & Yes & Stray & Dermatitis & & + & + & - \\
\hline 12 & 0.5 & $\mathrm{~F}$ & No & Stray & & & - & - & + \\
\hline 13 & 3 & M & Yes & Stray & $\begin{array}{l}\text { Lymphadenomegaly, apathy, anorexia, } \\
\text { dehydration weight loss, FRD***, } \\
\text { diarrhea, dermatitis }\end{array}$ & $\begin{array}{l}\text { Leukopenia, lymphopenia, } \\
\text { thrombocytopenia, } \\
\text { hyperproteinemia }\end{array}$ & - & - & + \\
\hline
\end{tabular}

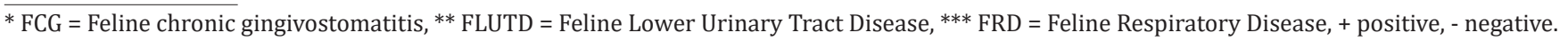


Regarding the clinical characteristics and habits of 88 cats, there was no statistically significant association with FIV infection and gender $(\mathrm{p}=0.39)$, and outdoor access $(\mathrm{p}=0.57)$. For FeLV and gender $(\mathrm{p}=0.68)$ and outdoor access $(\mathrm{p}=0.66)$, as FIV/FeLV with unneutered cats $(\mathrm{p}=0.32)$ there was no statistically significant association, but many of the cats had disturbance in the oral cavity (Table 2). The cats had not received vaccine for FIV or FeLV. The haematological findings of infected cats (Table 2) were not statistically different from the uninfected.

Of the 11 cats with FIV, all were positive by ELISA, but only six were also positive by nested PCR, with substantial agreement between the tests $(\kappa=0.678)$. The sensibility was $54.5 \%$ (CI: $23.4-83.3$ ) and the specificity was $100 \%$ (CI: 93.1-100) for detection the infection for FIV. Using the PCR, DNA was not detected Leishmania sp. in domestic cats.

\section{DISCUSSION}

The prevalence for FIV infection was higher than FeLV. It is contrasted by Munro et al. (2014) observed seroprevalence was $2.2 \%$ for FIV and $6.2 \%$ for FeLV in shelter cats in Canada, and Ortega-Pacheco et al. (2014) found 2.5\% for FIV, $7.5 \%$ for FeLV in owned cats in Mexico,that used the same test. This difference may have related to the sampled population of cats, either by free access to the street, high population density or poor hygienic conditions (Teixeira et al. 2007, Lara et al. 2008, Munro et al. 2014).

We did not find significant correlation between genders and outdoor access with FIV or FeLV infections, despite the infections is more frequent in cats with free access to the street, adulthood and unneutered males (Teixeira et al. 2007, Lara et al. 2008, Hartmann 2012). According Chhetri et al. (2015) outdoor exposure is more important to acquire FIV infection than FeLV, due increased opportunity for transmission via fights between cats.

Although there was no statistical difference, the hematologic findings of the infected cats were consistent with findings in other studies on these infections, several of which were performed on cats with neoplastic or non-neoplastic manifestations induced by FIV or FeLV (Hartmann 2012).

The clinical evaluation showed that $84.6 \%$ of the FIV/ FeLV-positive cats were sick, while $15.4 \%$ cats has none clinical alterations. Disorders of the oral cavity, and particularly stomatitis, may be associated with FIV infection in many cases and may be due to the immune response to chronic antigenic stimulation (Hartmann 2012).

ELISA is a sensitive technique capable of detecting early antigens as well as viraemia due to only transient FeLV infection that can be overcome (Meinerzs et al. 2010). For FIV infection, ELISA may provide sufficient sensibility for screening, while DNA PCR for FIV may have low sensitivity for detecting lentiviral strains because of low proviral load in blood cells (Franklin et al. 2007), which explains five cats are negative in this test.

Though the region studied here is endemic for visceral leishmaniasis and Leishmania sp. infection in wild felids (Dahroug et al. 2010), DNA was not found in any of the samples of cat tested. However, co-infection with FIV and
Leishmania has been described in an area endemic for visceral leishmaniasis in Brazil (Sobrinho et al. 2012).

\section{CONCLUSION}

The prevalence for FIV infection was higher than FeLV, and none factor was associated with the infection by FIV and FeLV in this study.

Acknowledgements.- The authors are grateful to BioBrasil (IDEXX Laboratories) for partial supply of the kits. This research received no specific grant from any funding agency of the public sector.

Conflict of interest.- The authors have no competing interests.

\section{REFERENCES}

Alves F., Rajao D.S., Del Puerto H.L., Braz G.F., Leite R.C., Mazur C., Martins A.S. \& Reis J.K.P.D. 2011. Occurrence of feline immunodeficiency virus and feline leukemia virus infection in cats. Am. J. Anim. Vet. Sci. 6:125-129.

Beatty J. 2014. Viral causes of feline lymphoma: retroviruses and beyond. Vet. Journal 201:174-180.

Chhetri B.K., Berke O., Pearl D.L. \& Bienzle D. 2015. Comparison of risk factors for seropositivity to feline immunodeficiency virus and feline leukemia virus among cats: a case-case study. BMC Vet. Res. 11:1-7.

Dahroug M.A.A., Almeida A.B.P.F., Sousa V.R.F., Dutra V., Turbino N.C,. Nakazato L. \& Souza R.L. 2010. Leishmania (Leishmania) chagasi in captive wild felids in Brazil. Trans. Royal Soc. Trop. Med. Hyg. 104:73-74.

Degrave W., Fernandes O., Campbell D., Bozza M. \& Lopes U. 1994. Use of molecular probes and PCR for detection and typing of Leishmania-a mini-review. Mem. Inst. Oswaldo Cruz 89:463-469.

Franklin S.P., Troyer J.L., TerWee J.A., Lyren L.M., Kays R.W., Riley S.P., Boyce W.M., Crooks K.R. \& Vandewoude S. 2007. Variability in assays used for detection of lentiviral infection in bobcats (Lynx rufus), pumas (Puma concolor), and ocelots (Leopardus pardalis). J. Wildl. Res. 43:700-710.

Hartmann K. 2012. Clinical aspects of Feline Retroviruses: a review. Viruses 4:2684-2710.

Hartmann K., Griessmayr P., Schulz B., Greene C.E., Vidyashankar A.N., Jarrett O. \& Egberink H.F. 2007. Quality of different in-clinic test systems for feline immunodeficiency virus and feline leukaemia virus infection. J. Feline Med. Surg. 9(6):439-445.

Lara V.M., Taniwaki S.A. \& Araújo J.P. 2008. Occurrence of feline immunodeficiency virus infection in cats. Ciência Rural 38:2245-2249.

Meinerzs A.R.M., Antunes T.A., Souza L.L., Nascente P.S., Faria R.O., Cleff M.B., Gomes F.R., Nobre M.O., Reischak D., Schuch L.F.D. \& Meireles M.C.A. 2010. Frequência do vírus da leucemia felina (VLFe) em felinos domésticos (Felis catus) semidomiciliados nos municípios de Pelotas e Rio Grande do Sul. Ciênc. Anim. Bras. 11:90-93.

Munro H.J., Berghuis L., Lang A.S., Rogers L. \& Whitney H. 2014. Seroprevalence of feline immunodeficiency virus (FIV) and feline leucemia virus (FeLV) in shelter cats on the island of Newfoundland, Canada. Can. J. Vet. Res. 78:140-144.

Ortega-Pacheco A., Aguilar-Caballero A.J., Colin-Flores R.F., Acosta-Viana K.Y., Guzman-Marin E. \& Jimenez-Coello M. 2014. Seroprevalence of feline leukemia virus, feline immunodeficiency virus and heartworm infection among owned cats in tropical Mexico. J. Feline Med. Surg. 16:460-464.

Pennisi M.G., Cardoso L., Baneth G., Bourdeau P., Koutinas A., Miró G., Oliva G. \& Solano-Gallego L. 2015. LeishVet update and recommendations on feline leishmaniosis. Parasit. Vectors 8:1-18.

Sambrook J., Fritsch E.F. \& Maniatis T. 1989. Molecular cloning: a laboratory manual. 2nd ed. Cold Spring Harbor Laboratory Press, New York, p.51-67.

Schmitt A.C., Reischak D., Cavlac C.L., Monforte C.H.L., Couto F.T., Almeida A.B.P.F., Santos D.G.G., Souza L., Alves C. \& Vecchi K. 2003. Infecção pelo vírus da leucemia e da peritonite infecciosa felina em felídeos selvagens 
de vida livre e de cativeiro da região do pantanal mato-grossense. Acta S. Vet. 31:185-188.

Sobrinho L.S.V., Rossi C.N., Vides J.P., Braga E.T., Gomes A.A., Lima V.M., Perri S.H., Generoso D., Langoni H., Leutenegger C., Biondo A.W., Laurenti M.D. \& Marcondes M. 2012. Coinfection of Leishmania chagasi with Toxoplasma gondii, Feline Immunodeficiency Virus (FIV) and Feline Leukemia Virus (FeLV) in cats from an endemic area of zoonotic visceral leishmaniasis. Vet. Parasitol. 187:302-306.
Teixeira B.M., Rajão D.S., Haddad J.P.A., Leite R.C. \& Reis J.K.P. 2007. Ocorrência do Vírus da Imunodeficiência Felina e do Vírus da Leucemia felina em gatos domésticos mantidos em abrigos no município de Belo Horizonte. Arq. Bras. Med. Vet. Zootec. 59:939-942.

Wilkes R.P., Kania S.A., Tsai Y.L., Lee P.Y., Chang H.H., Ma L.J., Chang H.F. \& Wang H.T. 2015. Rapid and sensitive detection of Feline immunodeficiency virus using in insulated isothermal PCR-based assay with a pointof-need PCR detection platform. J. Vet. Diagn. Invest. 27(4):510-515. 